\title{
An Analysis of the Narrative Mode of the Indian Film Hichki
}

\author{
Yanjuan Qi \\ Heilongjiang Bayi Agricultural University, Daqing, China \\ Email:25354716@qq.com
}

How to cite this paper: Qi, Y.J. (2019) An Analysis of the Narrative Mode of the Indian Film Hichki. Open Journal of Social Sciences, 7, 205-209.

https://doi.org/10.4236/jss.2019.712015

Received: November 11, 2019

Accepted: December 10, 2019

Published: December 13, 2019

Copyright $\odot 2019$ by author(s) and Scientific Research Publishing Inc. This work is licensed under the Creative Commons Attribution International License (CC BY 4.0).

http://creativecommons.org/licenses/by/4.0/

\begin{abstract}
The Indian realistic film Hichki focuses on the educational reality with the simple lens language and narrative mode, arousing the audience's laughter, tears, pain and kindling point, conveying a profound and distinct theme. The paper analyzes the narrative pattern, the integration of the linear narrative and emotional narrative in the movie.
\end{abstract}

\section{Keywords}

Linear Narrative, Emotional Narrative

\section{Introduction}

The Indian film Hichki made its debut in mainland Chinese theaters in 2018 and received a favorable reputation at the 21st Shanghai International Film Festival with zero negative reviews. The film focuses on the educational problems in India, especially the burp teacher with Tourette's syndrome, which not only shows the social vulnerable groups' difficulty in surviving in difficult situations, but also promotes the sacred mission of the teacher to teach and solve problems, and Hichki has also become a synonym for teacher. It is worth studying the narrative mode that the director employs behind the success of the reflection film.

\section{A Background Overview of Hichki}

The script of the India film Hichki, based on a true story, is from Brad Cohen's biographical novel Front of the Podium, which was adapted into the film Front of the Class in America. Indian film production team achieved its local creation based on the original and replaced the male protagonist with Indian female. The storyline has also been rewritten to incorporate Indian-style music and dance. The film fully shows the gap between the rich and the poor, Class Division, sur- 
name race and other issues in Indian society, focusing on the issue of educational equity, and as a sister film with Hindi Medium [1].

After the film was introduced into China, it was deeply loved by the Chinese audience, especially worthy of reflection by the Chinese film industry. Chinese films on education issues can be traced back to Zhang Yimou's Not One Less. In recent years, most of the campus movies have focused on campus love, and there are few films that directly touch on issues of educational fairness and reality. Therefore, the release of Hichki has aroused a heated debate on education among the Chinese people, and put forward a better demand for the creation of educational realistic movies in the Chinese film industry.

\section{The Analysis of the Linear Narrative Model in the Film}

In the narrative model, Hichki shows the new concept Indian film in a solid, earthly, sincere and critical way by combining the linear narrative with the emotional narrative. It is easy to think in the shadows and realize the cultural function of the film to convey thinking.

Throughout the narrative style of the new concept Indian film, there are more linear exposition compared with complicated communication of the expressive techniques, and Hichki uses a linear narrative model, which divided into the main line and the sub line. The main line starts with Naina's teaching career at school. The film begins with a sunny school, and the children's fun contrasts with the tension of Naina's waiting for the interview, leading the audience into the world of "hiccup" Naina. After five years' perseverance for the teacher position and being rejected for 18 times, Naina eventually waiter for her alma master St. Knox's appointment invitation, which became the turning point of the career for Naina. Only 14 students, from the slums, had poor grades, and Class 9F, labeled troublemaker, became Naina's first class. As you can imagine, the class initially did not accept Naina, and created a variety of practical jokes. However, Naina used a piece of chalk to inspire the students' courage to change the situation. As the story progresses, Nina lets the children and her slowly accept and like each other by taking classes on the playground, qualifying for the badge, visiting the slum, flying the paper plane full of fear, and inventing the gesture of finding the Polaris, which closes the distance between heart and heart. All these are accompanied with the continuous conflict between Class $9 \mathrm{~F}$ and other teachers and students in the school, and eventually Class 9F succeeds because of the trust and love between teachers and students, and Naina retired as the principal of her Alma Mater after many years. The subplot revolves around Naina's family. In the Indian realism theme film, many films choose family as the foothold, which is also related to India's strong cultural background. The film does not have much to say about the family, but it follows the narrative thread closely. As a mother and younger brother who silently supported Naina, it echoed the acceptance of Nina by President Khan. In contrast, the character of his father leaves the family, and his parents' arguments over whether Naina is normal or not, or- 
dering for her twice, and arranging for work all reveal the anguish that Tourette Syndrome brings to Naina. With the development of the main line, her father witnessed the students' apologies to Naina and the tightly embrace between teacher and students, all of these deeply touched this male chauvinist father, and finally resolved the gap between the father and the daughter for many years.

The vivid characterization, the fluent plot and the clear narrative thread form the complete linear narrative structure, and realize the seamless connection of the narrative clue. In order to avoid the burnout caused by linear expression, suspense is created through the setting of the plot, and the exciting drama conflict makes the audience cry when crying, laugh when laughing, and some netizens said that they can use minutes to calculate the burden in the film. In fact, this also reflects the journey of education cannot be plain sailing, and students will be full of problems. This is the normal state education.

\section{The Analysis of the Emotional Narrative Model in the Film}

Leo Tolstoy believes that without emotion and the infectious power of emotion, there would be no art, and emotion has become an indispensable core element in literary and artistic activities. The sincerity, aesthetic and infectious nature of emotion is connected with the value of literary works closely [2]. The film has formed its own emotional narrative mode by means of language containing feelings, details conveying feelings, feelings blending with scenes, feelings blending with reason and so on.

\subsection{Language Containing Feelings}

Words are the voice of the heart, and the individualized language in the literary context reflects the portrayal of the soul and personality of the characters, with great penetration and appeal. When Principal Khan told Naina, "you will receive the same treatment and the same education as well as the other students" and there was a round of applause. These words became Naina's motivation and the conviction of going forward. At this time, Nina's voice-overs for ordinary teachers, excellent teachers and great teachers are directed at the hearts of the people, and they are so painful. They are not only the irony of the literary language to the current reality of the teacher's "small under the bag", but also the expectation of the shaper teacher. Meanwhile, the teacher's enlightenment to the students' lives, which is also the belief in Naina's following teaching career as well, buried the foreshadowing of the subsequent development of the story. From His father once seeing Naina's hiccup as a dog, to finally saying, "I am proud of you", it describes Naina's father's huge change in his perception of Naina in just a few words, which implies his identity as a teacher.

\subsection{Details Conveying Feelings}

The importance of details in narrative works is self-evident, and small events, actions or links are often the finishing touches that can impress people. The 
protagonist is a Tourette syndrome who can't control hiccups, and the character, Rani Mukherjee, doesn't have this disease, so it is necessary to faithfully reproduce the patient's condition, and not to allow the disease over-exaggeration and grasping the degree of detail in the details is crucial to the player and it has become the biggest detail that the film needs to deal with. Starring Rani Mukherjee, who said she learned about these people through the Internet, "It's hard to show this state of mind, not just to imitate it, but to think about it, so that everyone can really feel it." The mixture of sadness and anger is hard to grasp on its own, but it also requires the conscious addition of "involuntary" movements and sounds to let the audience feel the changes of the protagonist's psychology and consciousness, and the protagonist's optimistic attitude, overcome obstacles, get recognition of the growth process of resonance, can become a model of inspiration. The film won the Academy Award for Best Actress again for its unalloyed performance.

\subsection{Feelings Fusion with the Natural Setting}

It is very common in literary works to paint the scenery in the shape of objects and express feelings in the scenery. There are two emotional scenes in the film about Naina. First, little Naina heard her parents quarreling because of her illness. She is sad and helpless. She sits in the toilet and stuffs her mouth with paper, hoping to control her hiccups. Her big eyes were full of tears and she was so small that she didn't know why she was different from other children and why the world had given her so much unfairness. Second, when Attiches was suspended from Class 9F for damaging her school's National Science and Technology Exhibition, she smashed the window, bit her hand, cried, scratched her hair and even slapped herself in the face at the end of the corridor of the teaching building. Anger, despair, not reconciled to all kinds of emotions through action, through the voice conveyed, watching on the heart-wrenching. These two scenes are used to express the complex inner feelings of Naina incisively and vividly, firmly grasped the audience's adrenal gland and earned enough tears.

\subsection{Feelings Blending with Reason}

"It is not enough to shock", said Madame de Stael, a French woman writer, "but to illuminate". The combination of reason and reason can make the views expressed by the works more easily recognized by the audience. After damaging the school project, Oulu jabbed Attiches's chest and said, "Her (Naina) stutter is in her mouth, your stutter is in your heart" and it prompted Attiches to reflect in shock. Attiches throws the bottle away in the misty night, which suggests Attiches has put down his self-righteous pride and arrogance and came to the platform where the children often gather with Killam. The tears in Attiches's eyes were visible in the high light, and the children hugged each other for the first time, which became the symbol of the transformation of Attiches. At the time of the students' intense review, Attiches prepared to hand out the questions, which 
had been leaked by the staff, but was refused. At this moment, even the students who are born in slums and have very poor grades have been deeply infected by Naina. On the surface, they refuse to test questions. In fact, children want to use fair competition to prove their worth. The test is not simply a result; it is a test of children's personality, the trust of teachers and students. There is no enlightenment, only moving, and the film delivered a full positive energy.

Based on educational issues, the film Hichki resonates with the audience with its simple Lens Language and narrative context, and achieves the artistic effect of conveying values and positive energy. The unique happy ending with a romantic color writes the desire for dreams [3]. Whether the film itself or the educational reality reflected in the film is worth the Chinese literary and artistic circles and educational circles to ponder over.

\section{Conflicts of Interest}

The author declares no conflicts of interest regarding the publication of this paper.

\section{References}

[1] Ye, Y.L. (2018) The Artistic Characteristics of New Concept Indian Films and Its Enlightenment to Domestic. Media, 10, 79-81.

[2] Chen, W.J. (2018) Emotional Narrative in News Reports. News and Writing, 11, 103-107.

[3] Han, H.Y. (2018) With Love as the Background, Indian films Can Transcend National Boundaries. Beijing Daily, 3, 8 . 